NBER WORKING PAPER SERIES

LESSONS ON MONETARY POLICY FROM THE 1980S

Benjamin M. Friedman

Working Paper No. 2551

NATIONAL BUREAU OF ECONOMIC RESEARCH 1050 Massachusetts Avenue

Cambridge, MA 02138

Aprił 1988

The research reported here is part of the NBER's research program in Financial Markets and Monetary Economics. Any opinions expressed are those of the author and Harry Bradley Foundation is gratefully acknowledged. 
NBER Working Paper \#2551

April 1988

Lessons on Monetary Pollcy from the 1980 s

ABSTRACT

\begin{abstract}
Monetary policy events in the United States during the 1980 s have led to important changes in thinking about monetary policy and in the actual conduct of policy. The central event in this regard has been the collapse of relationships connecting familiar money to both income and prices. The fastest money growth since World War II, maintained for fully half a decade, occurred in conjunction with the greatest post-war reduction in inflation. Inflation predictions based on money growth during this period therefore failed altogether to anticipate what many observers have regarded as the most significant monetary policy success of the post-war period. Predictions based on credit aggregates would have fared no better.

Other important changes have resulted from the increased openness of the U.S. economy and the U.S. financial markets. International considerations that previously could have mattered in a policy context, but typically did not, have reached macroeconomically meaningful magnitudes in the 1980s. The sharp decline in U.S. competitiveness, following the rise in dollar exchange rates early in the decade, powerfully affected U.S. nonfinancial economic activity. The borrowing that the United States has done to finance the resulting trade deficit has greatly enhanced the role of foreign investors in U.S. markets. Exchange rates have therefore assumed new importance in the conduct of U.S. monetary policy.
\end{abstract}

Along with exchange rates, short-term interest rates have again emerged as the principal focus of policy. Economic research would probably prove more useful in a policy context if economists turned at least some of the efforts they have devoted to trying to resurrect money-income and money-price relationships to analyzing how to conduct monetary policy without them.

Benjamin M. Friedman Harvard University

Littauer Center 127

Cambridge, MA 02138 


\section{LESSONS ON MONETARY BOLICY FROM THE 1980S}

\section{Benjamin M. Friedman*}

Harvard University

The half-decade running from mid 1982 to mid 1987 was a pretty good era for U.S. monetary policy, as these things go. A sharp easing of policy, beginning some time around midyear 1982, helped set in motion a recovery from the most severe business downturn the United States had experienced since the 1930 s - - a downturn that tight monetary policy earlier on had deliberately brought about in order to slow the alarming acceleration of prices. The recovery that ensued developed into a sustained expansion that continued without interruption through the end of 1987, thereby setting a new record for the longest recorded business expansion in U.S. peacetime experience. A fiscal policy based on unprecedentedly large (and continually growing) structural budget deficits was a major factor underlying this record-length expansion, but at least monetary policy did not stand in the way. Just as importantly, the severe 1981-82 recession served its intended purpose of substantially restoring price stability, and even after five years of expansion inflation remained modest by recent historical standards. At least as judged by these outcomes for the standard objectives of macroeconomic policy, U.S. monetary policy was a distinct success during these years.

Economists hoping to say something useful about monetary policy have had a tougher time. The quantitative relationships connecting income and price movements to the growth of familiar monetary aggregates, including especially the M1 measure of the money stock that had been the chief focus of monetary 
policy during 1979-82, utterly fell apart during this period. 1 Moreover, the collapse of these long-standing empirical regularities was not merely a matter of larger than usual quarter-to-quarter or year-to-year variances around longer-run benchmarks that otherwise continued to be reliable. Double-digit Ml growth, sustained on average over fully five years, repeatedly led prominent economists who had relied on these relationships in the past to offer widely publicized warnings of an immanent re-acceleration of prices. Yet the inflation rate fell dramatically, and then remained low. The presumption that "Inflation is always and everywhere a monetary phenomenon" became progressively less compelling as a substantive rather than merely tautological description of the determination of prices.

Economists who preferred to think about monetary policy in different terms had no more success in fitting the major developments of this period into some alternative conceptual framework. Relationships connecting income and prices to the monetary base, or to measures of credit, fell apart just as visibly as did those centered on Ml. Although real interest rates declined somewhat from the record levels posted in 1981 and early 1982, they nevertheless remained historically high throughout the next five years. Yet the economy's rate of growth in after-inflation dollars was about average for post-war business cycle expansions, and in this case the expansion continued on for five years without even a single negative quarter.

In the meanwhile, the rapidly changing structure of the United States' international economic position brought importance of a whole new magnitude to complications that most economists addressing questions about $U . S$. monetary policy had acknowledged often enough in the past, but nonetheless had usually ignored in substance. The U.S. current account balance, which had frequently 
$-3-$

changed sign since World War II but had always remained trivially small in comparison to the economy's size, suddenly became large enough to matter in a domestic macroeconomic context. The dollar exchange rate therefore emerged as a primary focus of U.S. macroeconomic policy. In addition, just within these few years the steady string of mounting current account deficits transformed the United States from the world's largest creditor country to the largest debtor. The exchange rate therefore acquired a new importance in the U.S. financial markets as well.

In the eyes of many economists, the Federal Reserve System has been steering without a rudder ever since it effectively abandoned its commitment to monetary growth targets in 1982. The visible success of monetary policy during the past half-decade is therefore all the more puzzling. In fact, over the course of this period the Federal Reserve's conduct of monetary policy appears to have centered ever more closely on controlling short-term interest rates. Whether this development really means that U.S. monetary policy has now returned to the conceptual basis of a quarter-century ago, when short-term nominal interest rates (or their equivalent) were practically the only focus of the policy process, remains unclear. At the very least, it raises the issue of whether the blatant flaws that crippled this policy strategy in the past were inherent and unavoidable. The other side of the same question is what will happen if the Federal Reserve continues to pursue what is basically an interest rate strategy, if and when inflation again becomes a major problem.

The 1979-82 Experiment and Its Aftermath

The basic facts describing the conduct of U.S. monetary policy in recent years are well known, although their interpretation has been the subject of 
much disagreement. In October 1979, the Federal Reserve System announced that it was adopting a new policy strategy placing primary emphasis on reducing over time the growth of the money stock. Further, to gain better control over money growth the Federal Reserve would be implementing new operating procedures, based in the first instance on the stock of nonborrowed reserves rather than the federal funds rate or some other short-term interest rate. The bands within which the federal funds rate would be free to fluctuate in the interval between meetings of the Federal Open Market Committee were accordingly widened by more than an order of magnitude. Several more narrowly technical measures, designed in principle to enhance control over money growth, were also part of the overall package.

The immediate motivation underlying this dramatic move was the rapidly deteriorating inflation situation, together with growing concerns about the dollar exchange rate. The overall U.S. inflation rate, as measured by the GNP deflator, had risen from a post-recession low of 6.48 in 1976 to 8.98 in 1979 . The comparable rise measured by consumer prices was from 4.88 to 13.38 , the highest rate since 1946. At the same time, dollar exchange rates declined between 1976 and 1979 by 16.48 on a trade-weighted basis (14.58 after correcting for differential inflation). Especially once the OPEC cartel announced yet another major hike in crude petroleum prices, fears of an uncontrollable inflation spiral or a precipitous decline in the dollar, or both, began to spread.

Although the Federal Open Market Committee had at least mentioned money growth targets in its formal policy directives ever since 1970, and had formally reported money growth targets to Congress since 1975, in practice there was little correspondence between the stated targets and actual money 


$$
-5 .
$$

growth. Evidence from the 1970s shows that the Federal Reserve did systematically adjust the federal funds rate in the direction required to offset deviations of actual money growth from the targets, but that the magnitude of these adjustments was far too small to be effective for plausible estimates of the interest elasticity of money demand. ${ }^{2}$ Perhaps more importantly, the Committee typically did not set the coming year's targets so as to make up for past deviations, but instead let bygones be bygones and so treated each year as independent of the past. As the years rolled on, the difference between actual and targeted money growth was usually positive, and the average difference was positive. As a result, the actual rate of Ml growth gradually drifted upward, from 4.98 per annum during 1965-69 to 6.18 per annum during 1970-74, and then 7.18 per annum during 1975-79 (although the fastest growth for any year during this period, 8.48, occurred during 1972).

The effects of the new combination of policy strategy and policy tactics implemented in October 1979 were Immediately visible, and they continued to be so for the next several years, although in some aspects they ran counter to the new policy's declared intent. At the most basic level, the Federal Reserve did carry through on its commitment to contain, and then reduce, the growth rate of the $M 1$ money stock. The rate of $M 1$ growth, measured from the fourth quarter of one year to the fourth quarter of the next (the same basis used for officially reporting money growth targets to Congress) had been 8.28 in 1978 . The "gradualist" objective of reducing the money growth rate by one percent each year, until it reached a level consistent with price stability, would imply targets of roughly 78 for 1979,68 for 1980,58 for 1981 , and so on. 3 Although MI had grown at .. 9.08 per annum rate in the first three quarters of 1979, with the sharp policy shift in the final quarter the growth for 1979 as a 
$-6-$

whole was 7.98 . A continuation of the new policy delivered $7.38 \mathrm{Ml}$ growth in 1980, and 5.18 in 1981 (see Figure 1). For this three-year period viewed as a whole, the new policy did manage to achieve results roughly consistent with the objective of reducing the money growth rate by one percent per year.

Not surprisingly, delivering on this objective involved interest rates that were both higher on average and also more volatile. ${ }^{4}$ Nominal interest rates immediately rose to record highs, and then declined sharply as the economy entered a recession and the Federal Reserve Board also imposed credit controls as authorized by President Carter under the Credit Control Act of 1969. ${ }^{5}$ Nominal interest rates then rose to yet new record highs in 1981 after business began to recover and credit controls were no longer in effect. Interest rates were high in real terms as well. The difference between the three-month Treasury bill rate and the next quarter's inflation rate, which had averaged close to zero during the post World War II period up until then, fluctuated in the 4-88 per annum range throughout 1981 and 1982. Short-run volatility of interest rates .- month-to-month, day-to-day, and even within the trading day -- increased by what for most measures were large multiples.

The most striking respect in which the results of the new monetary policy did not correspond to its declared intent was that the short-run volatility of money growth increased sharply too. The Federal Reserve's success in gradually reducing the yearly $M 1$ growth rate -8.28 in $1978,7.98$ in $1979,7.38$ in 1980 , 5.18 in 1981 .. did not carry over to the quarterly growth rate, which varied in the immediate post-1979 period from a high of 21.18 per annum in 1980:Q3 to a low of minus 5.8 per annum in 1980:Q2, nor to any finer time calibration. The standard deviation of $M 1$ growth from one quarter to the next jumped from 2.378 per annum during 1970:Q1-1979:Q3 to 6.648 per annum during 1979:Q-4-1982:Q2 (although omitting the two back-to-back extreme quarters 


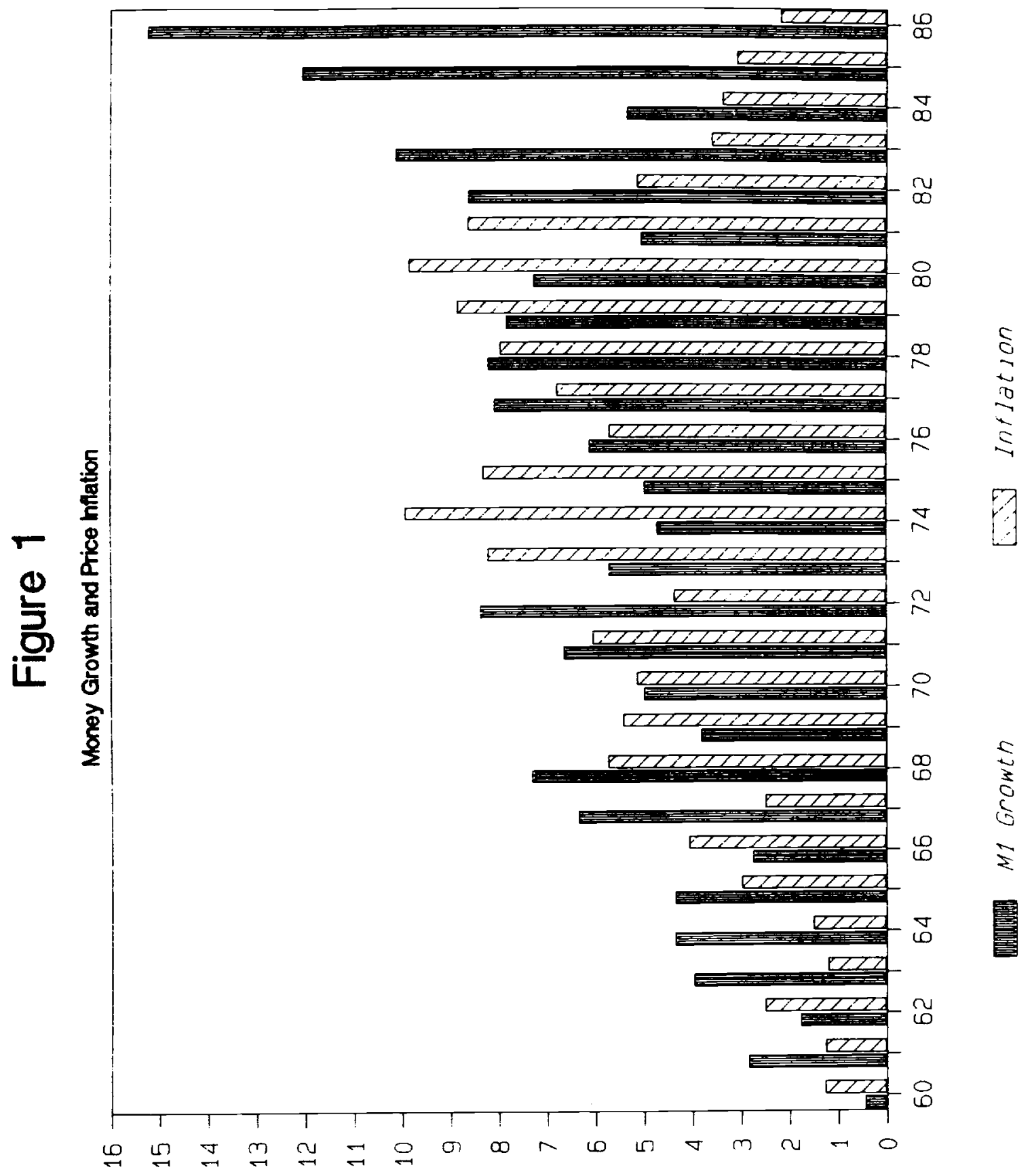

sej8y lonuuY phoolod 
$-7$.

during the 1980 credit control episode, the increase was only to 3.008 per annum.) Although the Federal Reserve had never formally acknowledged any commitment to stabilize money growth on a within-year basis, critics of monetary policy, both at the time and subsequently, focused on this increase in short-run volatility as casting doubt on the strength of the central bank's commitment to money growth targets in a broader perspective.

The monetary policy experiment that commenced in October 1979 ended almost as abruptly as it had begun. By the summer of 1982 the slowdown in U.S. business activity had developed into what was, by many measures, the most severe recession since the great depression of the 1930s. Unemployed labor, idle industrial capacity and business bankruptcies were all at post-war record levels. At the same time, bank failures had also reached record levels, and there were increasing signs of fragility throughout the financial structure. In August 1982 an impasse over Mexico's ability to meet its dollar-denominated external obligations called widespread attention for the first item to the debt problems not just of Mexico but of developing countries throughout Latin America and sub-Saharan Africa.

Yet the demand for money balances continued to be strong. Following the 5.18 growth in 1981, the Federal Reserve had set a $21 / 2-51 / 28$ target range for Ml growth in 1982 . The revised data now available show that actual Ml growth was within this range (4.68 per annum) during the first half of 1982; but the data available at that time showed Ml growth running consistently above the stated target range, despite continuing high interest rates and contracting real economic activity. In August the Federal Reserve allowed short-term interest rates to drop by almost three percentage points notwithstanding the emergence of still more rapid money growth. In October, within less than a 
week of the third anniversary of the announcement that had proclaimed the new dedication to money growth targets, Federal Reserve Chairman Paul Volcker publicly acknowledged that the Ml growth target was no longer in effect. With a further speed-up in the fourth quarter, Ml growth for the year 1982 came to 8.68 - above the target range, above the 1978 growth rate from which the program of cutting back on money growth had originally begun, and even above the post-war record growth rate set back in 1972 .

The experience of the next five years largely continued the course set in the latter half of 1982 . The yearly $M 1$ growth rate was in double digits in each of 1983, 1985 and 1986 (see again Figure 1). For the five-year span ending at mid 1987, the average Ml growth was 10.88 per annum. Only in 1984 did actual money growth fall within the stated target range. In both 1983 and 1985 the Federal Reserve officially changed the target range at midyear, once the difference between actual and targeted Ml growth became obvious. In 1986 the Federal Reserve suspended its Ml target range without setting a new one. In 1987 the Federal Reserve simply set no target range for Ml growth at all.

Throughout the post-1982 period the Federal Reserve's official pronouncements continued to emphasize targets for broader monetary aggregates in place of $\mathrm{Ml}$, but it is not clear to what extent these measures genuinely guided monetary policy. Actual M2 growth did fall within the stated target range in every year between 1983 and $1986 .^{6}$ Actual M3 growth exceeded the stated target range in 1983 and 1984, but fell within it in 1985 and 1986 . In 1987. until the October drop in stock prices, the Federal Reserve either instigated or accepted (depending upon one's perspective) rising market interest rates, and also raised the discount rate, despite the fact that both M2 growth and $M 3$ growth were falling short of the stated target range; and the decline of market interest rates immediately after the stock market crash 
appeared to have little to do with money growth patterns in any direct way.

By contrast, short-term nominal interest rates since 1982 have resumed the smooth pattern characteristic of the pre-1979 era, thereby suggesting a renewed role for interest rates - as before - at the center of the monetary policymaking process. The standard deviation of the month-to-month change in the three-month U.S. Treasury bill rate, for example, had risen from .428 per annum between January 1970 and September 1979, to 1.548 per annum between October 1979 and September 1982. It dropped back to .328 per annum between October 1982 and June 1987. The standard deviation of the month-to-month change in the federal funds rate rose from .508 to 1.928 , and then fell to .388 , over the same three periods.

Although some of this return to interest rate smoothness on a month-to-month basis may simply have reflected the continuity of the business expansion and the absence of a re-acceleration of prices during this period, the pronounced stability of short-term interest rates over a substantial span of time more likely indicates the return to a monetary policy approach based on closely controlling interest rate movements. At the least, it presents a strong contrast to the behavior that the Federal Reserve has accepted for the monetary aggregates.

\section{Collapse of the Money-Income and Money-Price Relationships}

What makes this unusual record of monetary policy actions look so successful in retrospect is that the bizarre behavior of money growth in no way corresponded to the behavior of income or prices. The familiar relationships that had characterized prior experience simply disappeared.

Instabilities in the money-income relationship $\cdots$ or, in more sophisticated forms, the money demand function -. had actually begun to become 
$-10-$

more pronounced as early as the mid 1970s, and their appearance had already spawned a substantial new body of empirical literature even before the new monetary policy experiment had commenced in October $1979 .^{7}$ By 1980 the Federal Reserve System had already adopted a whole new set of definitions of the monetary aggregates, designed in part to overcome just such difficulties. A survey paper bearing the suggestive title "The Search for a Stable Money Demand Function: A Survey of the Post-1973 Literature," and including more than eighty references, was already in print in the Journal of Economic Literature before Paul Volcker acknowledged in October 1982 that the Federal Reserve was suspending its MI growth target. 8

As Figure 2 makes clear, however, the instability that generated so much concern and research in the pre-1982 period was small stuff in comparison to what followed. The figure plots the ratio of the Ml money stock to GNP for each quarter since the start of the redefined $M 1$ series in 1959:Q1. ${ }^{9}$ Through the end of 1980 , the Ml-to-GNP ratio displayed the familiar downward trend of roughly 38 per annum that most students of the money-income relationship had come to see as inevitable in the post-war period, with a standard deviation around this trend of only .0044 (in comparison to a 1980:Q4 value of .1466). After 1980 the Ml-to GNP ratio not only experienced wider fluctuations but even reversed course. A simple extrapolation of the 1959-80 trend implies a ratio of .1007 by $1987: Q 2$ (the last quarter plotted). The actual value in $1987: Q 2$ was .1686, different from the trend extrapolation by more than 15 times the 1959-80 standard deviation.

Discussion of this phenomenon at the popular level has typically offered as an explanation the fact that "velocity" has declined. Because the so-called income velocity of money is nothing other than the ratio of GNP to money (the reciprocal of the ratio plotted in Figure 2), however, such explanations are 


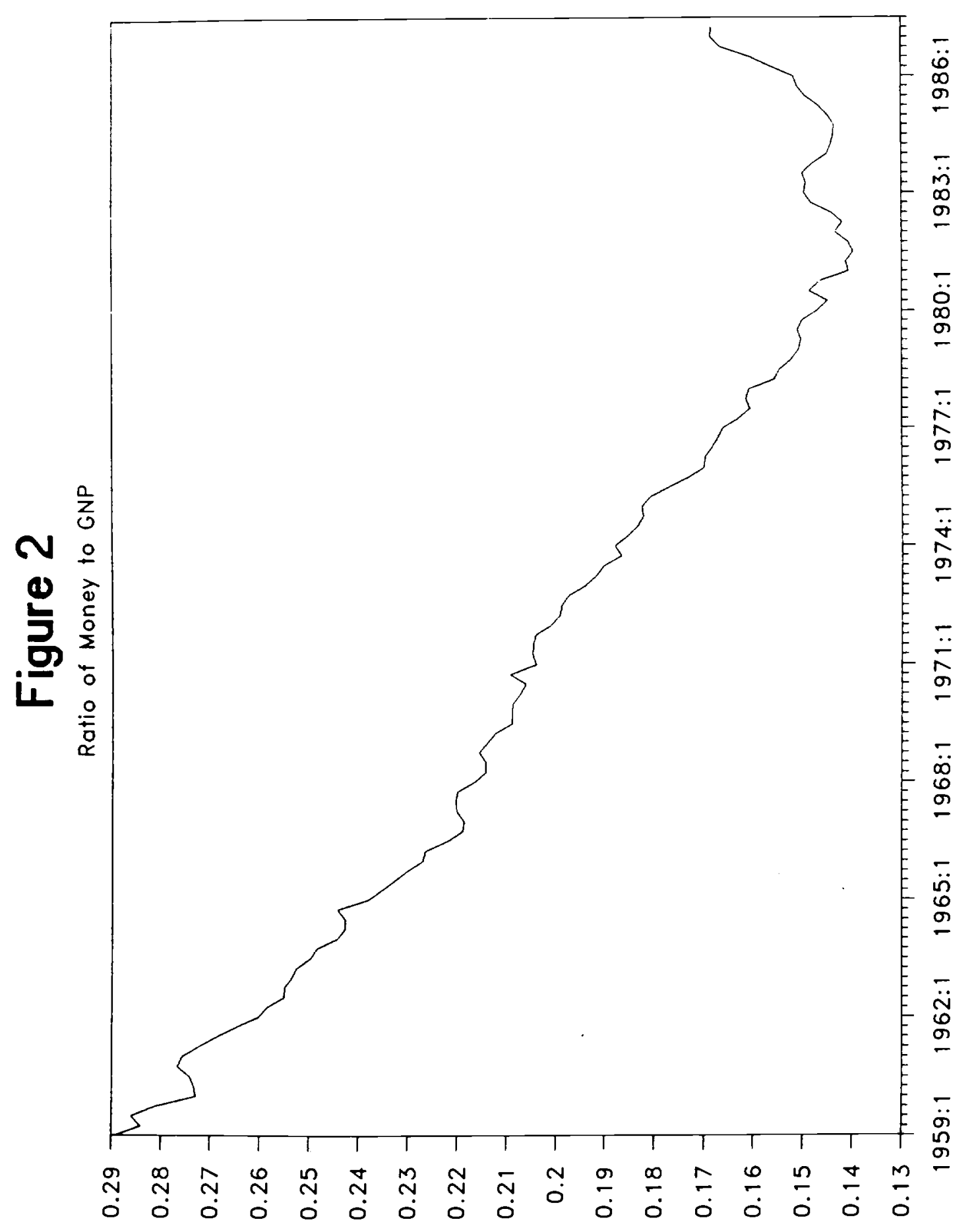


$-11-$

completely empty of content. Given the definition of "velocity" in this context, the fact that velocity declined is simply identical to the fact that money grew rapidly while income did not. Saying that money growth outpaced income growth because velocity declined is like saying that the sun rose because it was morning. 10

The mere fact of instability in the simple money-income ratio need not, of course, imply instability in more fully specified behavioral representations of the money-income relationship. The impression that stands out on a first glance at Figure 2 is representative of the results that researchers employing a variety of statistical strategies have found, however. A standard Goldfeld-type money demand function, estimated for quarterly data spanning 1952:Q3-1979:Q3, indicates a standard error of .428. Extending the sample to $1986: Q 4$ raises the standard error to .618 . Deleting the earlier data, so that the sample is $1974: \mathrm{Q} 2-1986: \mathrm{Q}$, further raises the standard error to .848 . Dynamic out-of-sample simulations of such equations deliver cumulative errors with root mean squares in the range of $4-88$ for different parts of the post-1982 period, in comparison with 0.5-1.58 for different parts of the pre-1974 period. Attempts to do better with alternative specifications have met at best only very limited success. 11

The story is approximately the same for efforts to investigate the money-income relationship from the perspective of determining income rather than money. A "St. Louis" type equation relating nominal GNP to four-quarter lags on both $M 1$ and high-employment government expenditures, estimated in logarithmic differences for quarterly data spanning 1960:Q1-1979:Q3, indicates an adjusted coefficient of determination $\left(\bar{R}^{2}\right)$ of .32 . Extending the sample to 1986:Q4 reduces the $\dot{R}^{2}$ to .11 . Deleting the earlier data, so that the sample is $1970: Q 3-1986: Q 4$, further reduces the $\bar{R}^{2}$ to just .02. More sophisticated 
$-12-$

autogression methods testing for a significant role of money in "causing" either nominal or real income, in the sense of accounting for income fluctuations not already accounted for by prior fluctuations in income itself, have produced results that are sufficiently varied to generate more skepticism than confidence in any strong conclusion on the subject, either positive or negative. 12

Finally, in considering the money-price relationship it is even necessary to be on guard against results that are strongly statistically significant but with the wrong sign to make any sense in economic terms. The double-digit average growth rate maintained for five years following mid 1982 represents the most rapid sustained money growth the United States has experienced since World War II, yet these same years also saw the strongest sustained deceleration of prices in the post-war period (see again Figure 1). Price inflation as measured by the GNP deflator peaked at 9.78 in 1981 and declined in each of the next five years, reaching 2.68 in 1986. The rate of increase of consumer prices peaked at 13.38 in 1979 and declined in all but one of the next seven years, reaching 1.18 in 1986 . Given the role that high-variance observations play in dominating results based on the least-squares methodology, as of the late 1980 s it is necessary to take care not to find results indicating that faster money growth implies slower inflation.

Two examples, both drawn from the same paper, readily illustrate the pitfalls that confronted anyone who continued to rely closely on straightforward money-income and money-price relationships during this period. First, Figure 3 is an expansion, both backward in time and forward, of a figure included in a 1984 paper by Milton Friedman in the American Economic Review, 13 The figure plots the respective annualized quarter-to-quarter growth rates of GNP and, with a one-quarter $1 \mathrm{ag}, \mathrm{Ml}$. The figure covers 


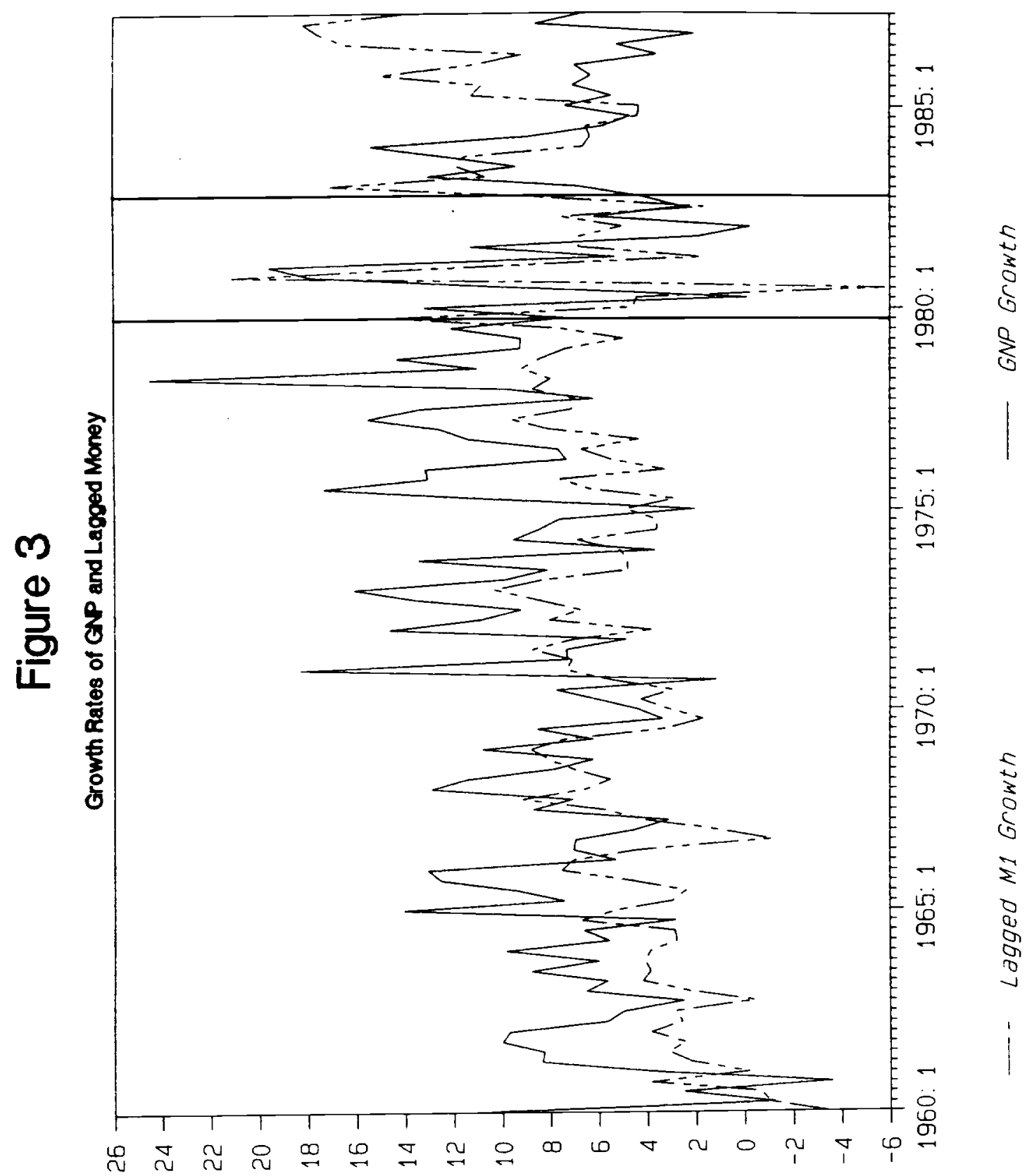

sejpy pencury proolod 
$-13-$

1960:Q1-1987:Q2 and distinguishes three time intervals. The middle one, 1979:Q4-1983:Q4, is identical to that plotted by Friedman. It spans the period from the October 1979 inception of the new monetary policy experiment through what was presumably the most recent observation avallable as of his time of writing.

After pointing out that the correlation between these two series during $1979: Q 4-1983: Q 4$ was .46 , or .71 after eliminating the two quarters affected by the credit control episode, Friedman wrote, "Two things are notable about the relation between money and income in these years: first, the lag is both shorter on the average and less variable than in earlier years, second, the relation is unusually close. I believe that both are a consequence of the exceptionally large fluctuations in M1 growth. The effect was to enhance the importance of the monetary changes relative to the numerous other factors affecting nominal income and thereby to speed up and render more consistent the reaction."

Table 1 summarizes the record of the GNP-to-lagged-Ml growth correlation and the varlability of $M 1$ growth for the three intervals shown in Figure 3 . Money growth on a quarter-to-quarter basis (as used by Friedman in his paper) was certainly more variable during 1979:Q4-1983:Q4 than it had been during the prior two decades. The GNP-to-lagged-Ml correlation was not "unusually close" during 1979:Q4-1983:Q4 compared to the past, however. The correlation of .45 computed over these eleven quarters (Friedman reported .46) is essentially Identical to that for the previous 79 quarters: Excluding 1980:Q2 and 1980:Q3 reduces the variability of money growth, but does not materially affect the GNP-to-lagged money correlation. (Subsequent data revisions have reduced the .71 correlation reported by Friedman to .47 as shown in Table 1 -. identical to the correlation for the earlier period.) 
TABLE 1

MONEY GROWTH VOLATILITY AND THE

GNP-TO-LAGGED-MI CORRELATION, 1960-1987

$\begin{array}{lcc}\text { Sample } & \begin{array}{c}\text { Standard } \\ \text { Deviation of } \\ \text { M1 Growth }\end{array} & \begin{array}{c}\text { Correlation Between } \\ \text { GNP Growth and } \\ \text { Lagged M1 Growth }\end{array} \\ \begin{array}{l}1960: Q 1-1979: Q 3 \\ 1979: Q 4-1983: Q 4\end{array} & 2.878 & .47 \\ 1979: Q 4-1980: Q 1,1980: Q 4-1983: Q 4 & 4.18 & .45 \\ 1984: Q 1-1987: Q 2 & & .47 \\ & 4.80 & -.10\end{array}$

Notes: Data are seasonally adjusted at annual rates.

Money data are quarterly averages. 
$-14-$

More importantly, what stands out in both Table 1 and Figure 3, is the change that occurred after 1983. Although the variability of money growth remained high, the positive GNP-to-lagged-Ml correlation disappeared entirely. In its place is a small negative correlation.

Table 2, focusing on the money-price relationship, is simply an updated version of a table that Friedman presented in the same 1984 paper. The horizontal line in each column indicates entries not included in the original version. 14 In describing the data shown above the two lines, Friedman wrote, "The long-period evidence suggests that Inflation has much inertia and that the lag between money and inflation is of the order of two years. Table [2] shows that this relation has held in recent years as well. There is a one-to-one relation between movements in monetary growth, and in the GNP deflator two years later over successive two-year periods since 1971 . . The increased rate of monetary growth in the 1981-83 biennium suggests that we have passed the trough in inflation and that inflation will be decidedly higher from 1983 to 1985 than it was from 1981 to $1983 . " 15$

As the below-the-line entries in Table 2 show, quite the opposite happened. Growth of MI during 1981:Q3-1983:Q3 was the fastest for any of the six biennia in Friedman's sample, but inflation in 1983:Q3-1985:Q3 turned out to be the lowest. Rapid money growth continued in 1983:Q3-1985:Q3, but inflation slowed still further in 1985:Q3-1987:Q3. The simple correlation between the two time series shown, calculated for the first five observations only, is .70. Calculated for all seven observations, the correlation is minus . 23 .

\section{Qther Koney and Credit Aggregates}

The breakdown of long-standing relationships to income and prices has not been confined to the Ml money measure. Neither M2 nor M3, nor the monetary 
TABLE 2

RATES OF CHANGE IN MONEY AND

IN INFLATION EIGHT QUARTERS LATER

Annual Rate of Change

Over Eight Ouarters

\begin{tabular}{|c|c|c|c|}
\hline Period for Money & M1 & $\begin{array}{l}\text { Deflator Eight } \\
\text { Quarters Later }\end{array}$ & $\begin{array}{l}\text { Period for } \\
\text { Deflator }\end{array}$ \\
\hline $1971: Q 3-1973: Q 3$ & 6.98 & 9.58 & $1973: Q 3-1975: Q 3$ \\
\hline $1973: Q 3-1975: Q 3$ & 5.28 & 6.3 & $1975: Q 3-1977: Q 3$ \\
\hline $1975: Q 3-1977: Q 3$ & 6.4 & 8.3 & $1977: Q 3-1979: Q 3$ \\
\hline $1977: Q 3-1979: Q 3$ & 8.6 & 9.4 & $1979: Q 3-1981: Q 3$ \\
\hline $1979: Q 3-1981: Q 3$ & 6.1 & 4.8 & $1981: 03-1983: 03$ \\
\hline $1981: 03-1983: 03$ & 9.2 & 3.3 & $1983: Q 3-1985: Q 3$ \\
\hline $1983: Q 3-1985: Q 3$ & 8.1 & 2.8 & $1985: Q 3-1987: Q 3$ \\
\hline
\end{tabular}

Notes: Data are seasonally adjusted.

Source: Friedman (1984), updated. 
$-15-$

Jbase, nor the total debt of domestic nonfinancial borrowers has displayed a consistent relationship to nominal income growth or to inflation during this period. On a quarter-to-quarter basis, standard relationships like Goldfeld-type equations fitting movements in these aggregates to movements of income and interest rates, or St. Louis-type equations fitting movements of nominal income to movements of an aggregate and a measure of fiscal policy, showed pronounced deterioration for each of these aggregates. (The largest $\dot{R}^{2}$ for any of these St. Louis equations, estimated for quarterly data spanning $1970: Q 3-1986: Q 4$, is .09.) On a longer-term basis, the average growth rate for each of these aggregates during the half-decade from mid 1982 to mid 1987 was in excess of any prior post-war experience; yet inflation lessened substantially, and the average growth of nominal income was hardly extraordinary. By mid 1987 the ratio of each aggregate to nominal GNP was above the level implied by an extrapolation of the corresponding pre-1980 trend by an amount ranging from three standard deviations (for M2) to twenty-three (for the credit aggregate), based on the pre-1980 variability. It is difficult to imagine how anyone could have successfully predicted the behavior of either income or prices during this period on the basis of foreknowledge of the path of any -. or, for that matter, all -- of these aggregates.

The manifest failure of the credit aggregate to perform satisfactorily in this context perhaps merits a special comment. I had earlier advocated the use of a broad credit aggregate in conjunction with one or more monetary aggregates, in formulating U.S. monetary policy, precisely on the ground that credit might provide some safeguard against false signals given by the monetary aggregates under conditions of instability affecting the public's demand for money. ${ }^{16}$ Because credit is a measure of activity on the liability side of the public's balance sheet, while the monetary aggregates are various measures 
$-16-$

of the non-bank public's assets, it seemed (and to me still seems) reasonable to think that expanding the information base explicitly underlying the monetary policy process, to encompass both money and credit measures, would provide potentially useful diversification in the context of portfolio behavior that is at best imperfectly understood, and inevitably subject to a multiplicity of shocks. In addition, empirical investigations relying on a variety of statistical methods indicated little basis for concluding that the total debt of all domestic nonfinancial borrowers was any less (or any more) closely related to movements of income or prices than was any of the standard monetary aggregates. 17

In the event, the movement of credit during the post-1982 period bore no more relation to income or prices than did that of any of the monetary aggregates. Worse still, the false signals provided by the growth of credit were in the same direction as those provided by the growth of money. Figure 4 plots the credit-to-GNP ratio for the same sample for which Figure 2 shows the M1-to-GNP ratio. 18 After decades of trendless stability, the credit ratio began an unprecedented climb in 1982 which has not stopped as of the time of writing. Moreover, disaggregated data show that essentially all categories of domestic nonfinancial borrowers - - including the federal government, state and local governments, individuals, and businesses - have played major roles in this extraordinary surge of indebtedness. 19 Anyone who had relied on prior credit-based relationships to predict the behavior of income or prices during this period would have made forecasts just as incorrect as those derived from money-based relationships. Anyone who had derived additional confidence in such predictions because the respective signals given by both money and credit confirmed one another would have found that confidence misplaced. 


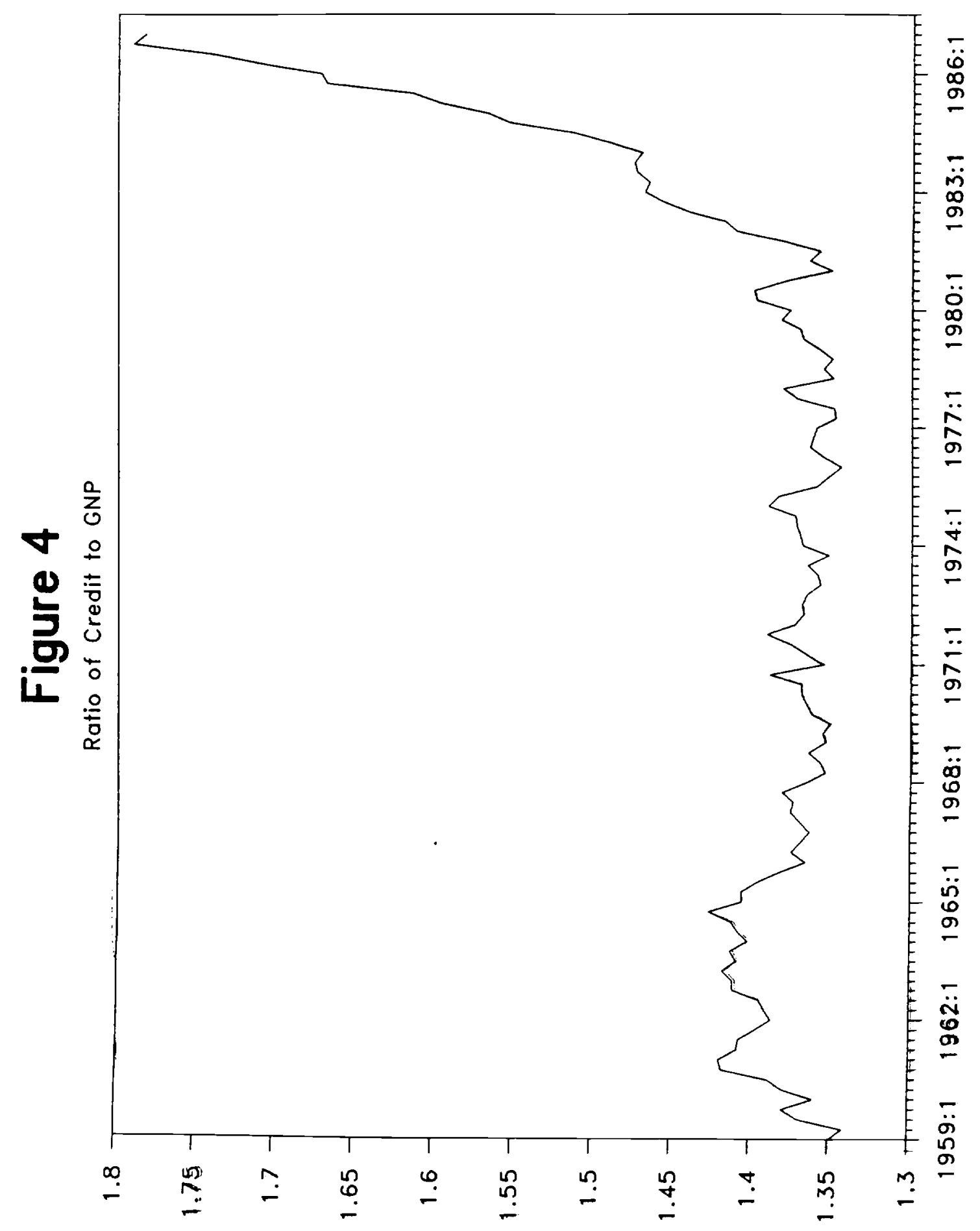


$-17-$

I have speculated elsewhere on the causes of the breakdown of the relationship between credit and income in the $1980 \mathrm{~s}^{20}$ For purposes of the monetary policy issues under discussion here, it is sufficient to say that attempts to "fix up" this relationship in any simple way are likely to be no more successful than such efforts directed at parallel relationships for the monetary aggregates have been.

\section{A Relationship That Did Hold Up}

In sharp contrast to the collapse of relationships connecting the ultimate objectives of monetary policy to standard quantity measures of policy actions, the long-standing relationship between the two most prominent macroeconomic policy objectives - - inflation and unemployment .- remained intact during this period. The point is of some interest because one of the principal supposed merits widely claimed in favor of the use of publicly announced money growth targets for monetary policy was a potential lessening of the real costs of disinflation. The idea was that public knowledge of such targets would affect expectations in such a way as to minimize (according to some models, to eliminate altogether) the usual negative impact of disinflationary monetary policy on employment, output, incomes, and profits.

What this idea should have led one to predict about the real costs of the major disinflation achieved in the United States in the 1980s is far from clear. For almost three years beginning in October 1979, the Federal Reserve did approximately carry through on its widely publicized intention to reduce the yearly rate of money growth by one percent per year - that is, as long as everyone understood that "money" meant Ml. Because the familiar claim that most measures of money move roughly together over time turned out to be false, however, anyone who watched $M 2$ or $M 3$ instead of $M 1$ would have seen no evidence 
$-18-$

of monetary deceleration. 21 Moreover, on a within-year basis even Ml growth became not more regular but less after October 1979 (see again Table 1). After mid 1982 there was no reason for anyone to find the Federal Reserve's commitment to its stated money growth targets credible.

Regardless of whether any part of the policy experience of the $1980 \mathrm{~s}$ constituted a good test for an effect of pre-announced money growth targets in reducing the real costs of disinflation, it is clear that no such reduction occurred. Ten years ago Arthur Okun surveyed a variety of econometric estimates of these costs, none of which incorporated any expectations effects due to reliance on pre-announced money growth targets. 22 okun's survey indicated that the cost of each percentage point reduction in inflation achieved by monetary policy would be between two and six "point-years" of unemployment, with a median estimate of three point-years. ${ }^{23}$ Table 3 shows the annual rate of change of the GNP deflator and the annual average unemployment rate beginning in 1978. The table also shows, for years beginning in 1980, the cumulative excess of the unemployment rate above 68 (the approximate average for the two prior years, and a standard "full employment" benchmark).

The slowing of inflation from nearly 108 per annum in $1980-81$ to roughly 3\% per annum a half-decade later required approximately 14 point-years of unemployment - right at the lower end of the range implied by the econometric models okun surveyed. Especially in light of the evidence suggesting that something like a third (and perhaps as much as a half) of this disinflation was a product of the 748 appreciation of the dollar's trade-weighted exchange rate between 1980 and early 1985 - an appreciation which has been almost entirely reversed as of the time of writing - this result seems fully consistent with Okun's prediction. 24 
TABLE 3

PERCENTAGE RATES OF INFLATION AND UNEMPLOYMENT, 1978-1987

1978
1979
1980
1981
1982
1983
1984
1985
1986
1987

Inflation

Rate

7.38

8.9

9.0

9.7

6.4

3.9

3.7

3.2

2.6

3.2 Unemployment
Rate

6.18

5.8

7.18

7.6

9.7

9.6

7.5

7.2

7.0

6.5
Cumulative

Excess Unemployment

1987

Note: Data for 1987 based on first half year only. 
$-19$.

Everyone had always known that sufficiently tight monetary policy, maintained for a sufficiently long time, could halt even the most deeply rooted inflation. The reluctance to proceed in that fashion lay not in disbelief that such a policy would do its job, but in concern for the resulting real costs. What was new beginning in October 1979 was the willingness to bear those costs.

\section{International Complications}

The United States is not a small open economy. U.S. production and U.S. incomes bulk sufficiently large in comparison to the combined economic scale of all countries participating in the current free international trading system that independent forces originating in this country can and do affect economic conditions on a world-wide basis. The U.S. financial markets bulk sufficiently large in comparison to world capital markets to exert analogous effects.

The United States is an open economy, however, and the increasing practical importance of this fact is perhaps the most interesting single development of the 1980 s from a monetary policy perspective. There are at least two major aspects of the U.S. economy's openness that now matter, far more than earlier on, for purposes of monetary policy. The more straightforward of the two is simply the demonstrated ability of U.S. exports and U.S. Imports to differ by a margin large enough to affect the economy's aggregate-level output and growth.

The possibility of such an outcome had always been present, of course; but throughout the post-war era, until the 1980s, the U.S. current account was always approximately in balance over periods long enough to even out the ups and downs of the business cycle. The current account was in surplus, albeit by less than $\$ 1$ billion per annum $(0.28$ of GNP), on average during the 1950 s. In the 1960 s the average annual surplus was $\$ 3$ billion $(0.48$ of GNP). In the 
1970s the current account was in deficit on average, but by less than $\$ 1$ billion per year (not even 0.18 of GNP). In 1980 there was a $\$ 2$ billion surplus, compared to overall GNP of $\$ 2.7$ trillion. It is little wonder that many analysts of U.S. monetary policy during these decades practically ignored potential effects on real economic activity via exchange rate channels.

The 1980 s have been starkly different. With a 748 appreciation of the dollar on a trade-weighted basis between yearend 1980 and early 1985 (648 after allowing for differential inflation rates), together with a host of other factors that may have further compounded the problem, the ability of many U.S. industries to compete in world markets all but collapsed. By 1986 the current account deficit was $\$ 141$ billion, or 3.38 of GNP. On an overall basis, including the trade balance, real GNP in 1986 was up over the 1980 level by 16.58. Excluding the trade balance - that is, focusing on domestic absorption rather than production - the increase over the six years was 23.38 . Not surprisingly, exchange rate effects on export and import flows have now emerged as a genuine focus of monetary policy concern, not just a subject for obligatory mention.

The more complex aspect of the newly enhanced importance of the U.S. economy's openness from a monetary policy perspective is an outgrowth of the first. A current account deficit means that a country is borrowing from abroad to finance the excess of its imports over its exports (where both are broadly defined) - - or, equivalently, to finance the excess of its domestic investment and government deficit over its domestic saving. Since 1980 U.S. fiscal policy has delivered an unbroken string of unprecedentedly large federal government budget deficits, notwithstanding five years of business expansion beginning in 1983. At the same time, domestic saving has been below average despite the introduction of a variety of supposed saving incentives. As a result, the 
$-21-$

United States has been borrowing from abroad in record volume even though the share of GNP devoted to net investment in both business and residential capital has been unusually small. Especially since 1984, the United States has borrowed from abroad on a larger scale in relation to the economy's size than the country did at any of the four peak periods of reliance on foreign capital to finance its canals, then its railroads, then its steel and other industries, and then its public utilities, during the nineteenth century. 25

This massive borrowing from abroad transformed the United States from the world's largest creditor country to its largest debtor in just four years. The U.S. net foreign asset position peaked at $\$ 141$ billion at yearend 1981 . It was still \$136 billion as of yearend 1982. The United States officially became a net debtor again (for the first time since before World War I) in early 1985. By yearend 1986 the U.S. net foreign debt was $\$ 265$ billion - more than that of Mexico, Brazil and Argentina combined. 26 on a gross basis (that is, without any balancing of U.S. holdings abroad) foreign holdings in the United States as of yearend 1986 came to $\$ 1.3$ trillion, including such readily 1 iquefiable assets as $\$ 267$ billion of U.S. Treasury securities, $\$ 149$ billion of corporate bonds and other debt securities, $\$ 167$ of corporate equities, and $\$ 477$ billion of bank deposits. 27

As a result of this surge in foreign holdings during the 1980s, foreign investors have assumed an importance in the U.S. financial markets that was previously unknown in modern times. Whether or not foreign investors will bid in volume on any given day's auction of U.S. Treasury securities is now of ten the paramount focus of attention among participants not just in the U.S. bond market but in the stock market too. Popular discussions frequently raise the fear that foreign investors might decide to "get out" of dollar holdings, with disastrous consequences for the dollar exchange rate as well as for the prices 
of dollar denominated securities. The notion that foreign investors in the aggregate can sell their dollar holdings to anyone but each other is mistaken, of course, but their attempts to do so can move both exchange rates and securities prices. In particular, given the size of foreign holdings, a widespread move to liquidate bond and equity portfolios as a preliminary to selling dollars (even if only to other foreign buyers) could easily move securities prices by a substantial margin. As a result, managing dollar exchange rates so as to prevent such occurrences has added a whole new dimension of U.S. monetary policy.

The contrast between the rigid hands-off attitude toward the foreign exchange markets that the Reagan administration espoused during its first four years in office, and the series of ad hoc international agreements that it has orchestrated beginning with the widely publicized meeting at New York's Plaza Hotel in September 1985, is just the most visible part of the increased importance of the exchange rate for the United States. Although there is little hard evidence as yet, it appears that the change has affected U.S. monetary policy in more ongoing, and more subtle, ways as well. For example, even at the simplest level it is no longer so obvious that an open market purchase which lowers short-term interest rates will necessarily lower long-term interest rates as well. If dollar exchange rates fall as a result of lower U.S. short-term rates, foreign investors may sell their long-term U.S. assets as a preliminary to reducing (again, not collectively) their overall dollar holdings, and domestic market participants may seek to do the same in anticipation of the action by foreign investors. 28

If the net result of these developments amounts to an erosion of sovereignty over U.S. monetary policy, that loss is no more than the inevitable price of becoming a debtor country - and the world's largest, at that. Losing 
$-23$.

control over one's affairs is part of what a mounting debt level is all about, no less for a borrowing nation than for business or individual borrowers. The policy actions and public discussions that ensued after the October 1987 stock market crash dramatically illustrated the tension that can arise under such circumstances between a monetary policy designed to support the currency and a monetary policy designed to prop up the domestic economy. At least thus far the United States' situation in this regard is not yet so constraining as, for example, Britain's was during the 1950 s and 1960s, when repeated ad hoc concessions were necessary to avert the eruption of a "sterling crisis." Even so, the problem of formulating and implementing U.S. monetary policy is now more complicated by one more dimension.

Vacuum at the Center?

It is difficult to escape the conclusion that there is now a conceptual vacuum at the center of the U.S. monetary policymaking process. The seemingly endless quest from various quarters to impose some kind of simple rule on the conduct of monetary policy is, at least for now, no longer a going concern. The interactions among money, income and prices during the 1980 s $\ldots$ including the half-decade that followed the monetary targets experiment, even more than what happened during 1979-82 - have undermined it both intellectually and practically. The claim that reliance on some kind of simple rule would open the way to costless disinflation is at best unproven, and for practical purposes dubious. The notion that some kind of simple rule would adequately encompass the new complications due to the increased practical importance of the U.S. economy's openness is dubious at best. In retrospect, the contemptuous dismissal by some economists of the Federal Reserve's reluctance to adopt the monetary policy rules they had proposed - and the readily voiced 
assumption that that reluctance could have stemmed only from ignorance or a faulty set of objectives on the part of Federal Reserve officials, or perhaps even their self-aggrandizement at the public expense - stands as a sorry reminder that economists outside government can also make each of these errors. The most powerful element of what has happened in this regard in the 1980 s is the collapse of the longer-run relationship between money on the one side and income and prices on the other. In this decade the main event has been very different from the quarter-to-quarter or even year-to-year irregularity that was always the focus of debate about whether these relationships were stable before. Proponents of simple monetary policy rules in the past could and did claim that such rules failed to offset short-run economic fluctuations that policy could probably not hope to eliminate anyway, but that over longer horizons the anchor they provided would keep the economy on a steadier course than an alternative policy that attempted to achieve "fine tuning." With nominal GNP by mid 1987 more than 408 below the value implied by the long-run relationship to $M 1$ which prevailed during 1959-80, the problem is no longer in the fine tuning but in the anchor itself.

The relevant issue here for policy purposes is not whether for any time interval there exists some abstract notion of "money" that conceptually bears a stable and reliable relation to income and prices, and that statisticians can seek to uncover after that interval ends, but whether policymakers can identify and measure that quantity substantially in advance of their need to base planing and operating decisions on it. Appeals to the tradition of the "quantity theory" are of no use in this context in the absence of a clear statement of what is the quantity and what is the theory. Especially in a world of institutions that increasingly blur the distinction between transactions balances and saving balances, being precise about either the 
$-25-$

theory or the quantity is ever more difficult. The continuing (indeed increasing) interest within the economics profession in some kind of Constitutional constraint on monetary policy jars harshly against the likelihood of what such constraints suggested (but not enacted) in years past would have meant in the 1980 s.

Nor is the problem merely one of money (or credit) "targets." The more flexible idea that such variables as money and credit, which are endogamous to the monetary policy process in the short run, should be used as "information variables" to guide the initial setting and ultimate readjustment of whatever genuinely exogenous instrument the central bank is using, has always seemed high attractive - at least to me. The information-variable approach to monetary policy makes no sense, however, in the absence of a reasonably compact set of variables that reliable provide information about the macroeconomic outcomes monetary policy is seeking to affect. After the experience of the 1980s, it is difficult to foresee any ready consensus on what that compact set of variables should be. Subsequent experience may provide a new basis for such a consensus, and new data to substantiate it; but that prospect remains a matter for the future, if not later still.

In the meanwhile, the Federal Reserve System has not ceased operations. Nor should it be inclined to do so, in light of the performance of both income and prices during the past half-decade. Five years of fairly steady economic growth, with inflation consistently lower than at any time since before the Viet Nam War, represents no small achievement by today's standards. In the world of practical affairs, it is difficult to argue with success.

Notwithstanding the Federal Reserve's continuing formulation of money growth targets that it reports to Congress, as current 1 aw requires, and even notwithstanding the relatively high success rate in meeting the target for $M 2$, 
$-26-$

it seems clear enough that the Federal Reserve System since mid 1982 has

centered its monetary policy actions primarily around controlling short-term nominal interest rates. ${ }^{29}$ In so doing, Federal Reserve decision makers have no doubt taken account of the movements of money (and perhaps credit, too); but they have also taken account of many other potential information sources, including longer-term asset prices and yields, dollar exchange rates, and numerous aspects of nonfinancial economic activity. More to the point, they have apparently proceeded in the absence of any well articulated conceptual framework linking the interest rate as the chief policy instrument to the main macroeconomic policy objectives, or linking the associated large and diverse information base to either the policy instrument or the policy objectives. Although procedures differ in various details, the overall approach is strongly reminiscent of the practice of the 1950 s and $1960 \mathrm{~s} .30$

It is therefore useful to ask why the policy approach followed at that time failed. The voluminous investigation of this question, both at the time and subsequently, supported three general conclusions: First, Federal Reserve officials systematically confused the level of interest rates as the instrument of monetary policy with the level of interest rates as an ultimate objective of monetary policy. As a result, they usually delayed too long before raising or lowering interest rate levels, and even then made changes of insufficient magnitude. Second, with no nominal quantity at the center of the policy process, the overall approach lacked an anchor to provide price stability. Although inflation was not therefore inevitable, there was little protection against it when various inflationary pressures arose. Third, once inflation did emerge, Federal Reserve officials (and many other people too) often failed to distinguish nominal from real interest rates. As a result, they often associated higher observed interest rates with a tighter policy stance even 
$-27-$

when the increase in nominal interest rates merely kept pace with, or even fell short of, rising inflation expectations.

Are these three flaws inherent in the approach to monetary policy that the Federal Reserve System followed a quarter-century ago, and that it has apparently been following again since mid 1982? Or is it possible to design and implement monetary policy along these lines, albeit in a way that has learned from the still relatively recent past? Were the familiar failures of monetary policy under this approach in the past inevitable? or does the experience of the last half-decade show that this kind of monetary policy can work, and work well? Research on these questions may be the best contribution economists concerned with U.S. monetary policy can now make. 
* I am grateful to Kenneth Kuttner for research assistance; to Stanley Fischer, William Poole, Joseph Stiglitz and Timothy Taylor for helpful comments on a previous draft; and to the National Science Foundation and the Harvard Program for Financial Research for research support.

1. The MI money stock consists of currency, checkable deposits (including both non-interest-bearing demand deposits and interest-bearing Now accounts) and travelers checks; its value as of June 1987 was $\$ 747$ billion. M2 consists of M1 plus a much larger quantity of savings-type accounts, including ordinary passbook accounts and certificates of deposit (in amounts up to $\$ 100,000$ ), money market deposit accounts and money market mutual funds (both of which can have limited checking facilities), and overnight repurchase agreements and Eurodollars; its June 1987 value was $\$ 2.8$ trillion. $M 3$ consists of $M 2$ plus institutionally oriented instruments like certificates of deposit in amounts over $\$ 100,000$ and money market mutual funds used by institutional investors, as well as repurchase agreements and Eurodollars extending beyond overnight; its June 1987 value was $\$ 3.6$ trillion.

2. See, for example, De Rosa and Stern (1977) and Lombra and Moran (1980).

3. The official Ml target range for 1979 was 5-88.

4. Increased short-run volatility of short-term interest rates, as a result of no longer accommodating temporary disturbances affecting money demand, is a straightforward implication of Poole's (1970) analysis of the money growth target strategy for monetary policy. Whether long-term interest rates should be expected to be more or less volatile is a more complicated question, however, involving changing risk factors and expectations of future inflation and interest rates.

5. The 1969 legislation under which the Board acted was quite far reaching, empowering the Federal Reserve Board, whenever explicitly authorized by the President, to "prohibit or limit any extensions of credit under any circumstances the Board deems appropriate." In 1980 the Board proceeded under this authority to impose special reserve-type requirements on increases in certain kinds of consumer credit by all lenders (including non-banks), on increases in deposits at money market mutual funds, and on increases in non-deposit liabilities at banks that were not members of the Federal Reserve System.

6. In 1983 the stated target range for $M 2$ growth covered only part of the year.

7. The standard reference to state first is the contrast between the findings in Goldfeld (1973) and Goldfeld (1976). The most widely read studies done at the time by the Federal Reserve's own staff include Enzler et al. (1976), Porter et al. (1979), and Simpson and Porter (1980). 
8. Judd and Scadding (1982).

9. The series plotted is the ratio of $\mathrm{Ml}$, as a quarterly average of monthly data (source: Board of Governors of the Federal Reserve System) to quarterly GNP at annual rates (source: U.S. Department of Commerce). Both series are seasonally adjusted.

10. I owe the analogy to William Bennett.

11. The specific results cited here are from Goldfeld (forthcoming), which also provides an extensive survey. Roley (1985) also showed the results of experimenting with a wide variety of alternative specifications.

12. See, for example, the differing results reported in Friedman (1986), Eichenbaum and Singleton (1986), and Stock and Watson (1987).

13. Friedman (1984).

14. The entries above the lines differ from Friedman's because of subsequent data revisions, but the differences are slight.

15. Friedman made the same prediction more forcefully in pieces directed at broader audiences. In a column in the September 26,1983 issue of Newsweek, for example, Friedman wrote, "Inflation has not yet accelerated. That will come next year, since it generally takes about two years for monetary acceleration to work its way through to inflation... The monetary explosion from July 1982 to July 1983 leaves no satisfactory way out of our present situation. . The result is bound to be renewed stagflation - - recession accompanied by using inflation and high interest rates." A lengthy interview in the March 19, 1984 issue of Fortune indicated that Friedman ". . . also sees a strong possibility that by the end of [1984] inflation could reach an annual rate as high as 98."

16. See, for example, Friedman (1982, 1983).

17. There are several obvious problems with attempting to measure the relevant concept of credit in this way. One is simply that the available data measure long-term debts at par value rather than at market prices (or some equivalent for nonmarketable debts). Another is that although the category of "nonfinancial" borrowers excludes any entity explicitly set up as a financial intermediaries, there is inevitably some degree of double-counting due to what amounts to financial intermediation carried out by ordinary businesses and even individuals. Whether this problem is more or less severe than comparable problems affecting the monetary aggregates $\cdots$ for example, the apparently widespread use of U.S. currency in black markets around the world, or even in the United States for a variety of purposes not related to familiar theories of demand for money - is an empirical question.

18. The data are analogous to those in Figure 2 except that the numerator is end of quarter outstanding debt of domestic nonfinancial borrowers (source: Board of Governors of the Federal Reserve System). 
19. The one exception is the farm sector.

20. Friedman (1987).

21. For the five years 1978-82, the simple correlations among the fourth-quarter-over-fourth-quarter growth rates of the major $M$ 's were each negative: -.53 between $M 1$ and $M 2,-.57$ between $M 1$ and $M 3$, and -.12 between $M 2$ and $M 3$.

22. Okun (1978).

23. A "point year" of unemployment is one percentage point of unemployment in excess of the rate that corresponds to "full employment, " maintained for one year. Some writers - for example, Fischer (1985) - - have focused on real output rather than unemployment, and have argued on that basis that the post-1980 disinflation involved smaller costs than Okun's survey implied. The focus of the evidence that Okun surveyed was the inflation-unemployment relationship, however. His translation of the cost estimate into foregone real output simply relied on the usual three-for-one "Okun's Law" relation, which has not held up during the 1980 s.

24. See, for example, Sachs (1985) for an analysis of the importance of the dollar's appreciation in the U.S. disinflation.

25. See Solomon (1986) for a review of the nineteenth century experience.

26. The official accounts include numerous obvious mismeasurements, but there is no ground for claiming that their sum is very different from zero. The largest adjustments in favor of the United States in a set of true accounts would be the revaluation of U.S. gold stocks, and of the net of U.S. direct investment abroad and foreign direct investment in the United states, to current market values. The largest adjustments against the United states would be the revaluation to market value of U.S. banks' loans to developing countries, and allowance for the accumulation over time of each year's "errors and omissions" flow.

27. These data are from Scholl (1987), Table 1.

28. The effect is analogous to that sometimes claimed along the lines that open market purchases would lead investors to sell long-term bonds out of fear that the resulting increase in money growth would bring higher inflation. Market experience in the United States has not borne out this earlier line of reasoning, but there appears to be more evidence to support the effect operating via exchange rates.

29. See Wallich (1984) for a description in different but equivalent terms.

30. See, for example, the descriptions given by Brunner and Meltzer (1964) and Guttentag (1966). 


\section{$\underline{\text { References }}$}

Brunner, Karl, and Meltzer, Allan H. The Federal Reserve's Attachment to the Free Reserve Concept, U.S. Congress (House of Representatives, Committee on Banking and Currency, Subcommittee on Domestic Finance), 88 th Congress, 2nd Session. Washington: U.S. Government Printing Office, 1964.

DeRosa, Paul, and Stern, Gary H. "Monetary Control and the Federal Funds Rate." Journal of Monetary Economics, 3 (Apri1, 1977), 217-231.

Eichenbaum, Martin, and Singleton, Kenneth J. "Do Equilibrium Real Business Cycle Theories Explain Postwar U.S. Business Cycles?" Fischer (ed.), NBER Macroeconomics Annual. Cambridge: The MIT Press, 1986.

Enzler, Jared, Johnson, Lewis, and Paulus, John. "Some Problems of Money Demand." Brookings Papers on Economic Activity (No. 1, 1976) 261-278.

Fischer, Stanley. "Contracts, Credibility, and Disinflation." Mimeo: National Bureau of Economic Research, 1985.

Friedman, Benjamin M. "Time to Reexamine the Monetary Targets Framework." New England Economic Review (March/Apri1, 1982), 15-23.

Friedman, Benjamin M. "The Roles of Money and Credit in Macroeconomic Analysis." Tobin (ed.), Macroeconomic. Prices and Quantities: Essays in Memory of Arthur M. Okun, Washington: The Brookings Institution, 1983.

Friedman, Benjamin M. "Money, Credit, and Interest Rates in the Business Cycle." Gordon (ed.), The American Business Cycle; Continuity and Change. Chicago: University of Chicago Press, 1986.

Friedman, Benjamin M. "New Directions in the Relationship Between Public and Private Debt." Science, 236 (April 24, 1987), 397-403.

Friedman, Milton. "Lessons from the 1979-82 Monetary Policy Experiment." American Economic Review, 74 (May, 1984), 397-400.

Goldfeld, Stephen M. "The Case of the Missing Money." Brookings Papers on Economic Activity (No.3, 1976), 683-730.

Goldfeld, Stephen M. "The Demand for Money Revisited." Brookings Papers on Economic Activity (No.3, 1973), 577-638.

Goldfeld, Stephen M. "Money Demand." Friedman and Hahn (eds.), Handbook of Monetary Economics. Amsterdam: North-Holland Publishing Company, forthcoming.

Guttentag, Jack M. "The Strategy of Open Market Operations." Quarterly Journal of Economics, 80 (February, 1966), 1-30.

Judd, John J., and Scadding, John L. "The Search for a Stable Money Demand Function: A Survey of the Post-1973 Literative." Journal of Economic Literature, 20 (September, 1982), 993-1023. 
Lombra, Raymond, and Moran, Michael. "Policy Advice and Policymaking at the Federal Reserve." Brunner and Meltzer (eds.), Monetary Institutions and the Policy Process. Amsterdam: North-Holland Publishing Company, 1980.

Okun, Arthur M. "Efficient Disinflationary Rules." American Economic Review, 68 (May, 1978), 348-352.

Poole, William. "Optimal Choice of Monetary Policy Instruments in a Simple Stochastic Macro Model." Quarterly Journal of Economics, 84 (May, 1970), $197-216$.

Porter, Richard D., Simpson, Thomas D., and Mauskopf, Eileen. "Financial Innovation and the Monetary Aggregates." Brookings Papers on Economic Activity (No.1, 1979), 213-237.

Roley, V. Vance. "Money Demand Predictability." Journal of Money. Credit and Banking, 17 (November, 1985), Part 2, 611-641.

Sachs, Jeffrey D. "The Dollar and the Policy Mix: 1985." Brookings Papers on Economic Activity (No.1, 1985), 117-185.

Scholl, Russell B. "The International Investment Position of the United States in 1986." Survey of Current Business, 67 (June, 1987), 38-45.

Simpson, Thomas D., and Porter, Richard D. "Some Issues Involving the Definition and Interpretation of the Monetary Aggregates." Controlling Monetary Aggregates III. Boston: Federal Reserve Bank of Boston, 1980.

Solomon, Robert. "The United States as a Debtor in the Nineteenth Century." Mimeo: The Brookings Institution, 1986.

Stock, James H., and Watson, Mark W. "Interpreting the Evidence on Money-Income Causality." Mimeo, National Bureau of Economic Research, 1987.

Wallich, Henry C. "Recent Techniques of Monetary Policy." Federal Reserve Bank of Kansas City, Economic Review (May, 1984), 21-30. 
</ref_section> 